\title{
Improving Ninth Grade Students' Comprehension in Learning Indonesian Language by Implementing Peer-Tutor Strategy in SMP N 2 Bintan
}

\author{
Ruslan Manurung ${ }^{1}$ \\ ${ }^{1}$ Corresponding author,SMP N 2 Bintan, Kepulauan Riau, Indonesia; \\ Ruslanmanurung9@gmail.com
}

\begin{abstract}
This research was based on the ninth grade students' lack of ability in using Indonesian language at SMP N 2 Bintan which it was supported by the number of students with passed-scores not more than 50\%. As a teacher and also a researcher as well, the daily observation showcased students' problems are being shy to ask and afraid of questioning in the classroom. Considering these in mind, Classroom Action Research (CAR) was conducted by implementing Peer Tutor Strategy as part of cooperative learning. The data collection method was a learning achievement test. The data were analysed and explained in descriptive way. The results of the study revealed Peer Tutor Strategy can improve student learning achievement. It was proved by the improvement of students' scores in two cycles. In the first cycle, the average score is 63.75 while in the second cycle is 80. From this significant improvement, the implementation of Peer Teaching Strategy is effective in improving students' Indonesian Language ability.
\end{abstract}

Keywords: Classroom Action Research, Indonesian Language, Peer Tutor Strategy, Teacher Professional Development

\section{Introduction}

\subsection{Background of the Study}

The direction of education in Indonesia according to a teacher to understand that teachers must be able to improve their competence, be able to carry out constructivist, competitive and creative learning based on a variety of intelligences built through a systematic and planned, intelligent, and competitive education management system that is moral, cultured, and understand the noble values supported by sophisticated technology and science.

Fuad Abdul Hamied, Advisor of ISPI and Director of the UPI Postgraduate School (2008) in his National Seminar Paper in Purwokerto explained that educators in carrying out their duties must teach with technology. There are three disadvantages needed in this case: information literacy, media literacy, and ICT literacy. First: Information Literacy is characterized by the ability to access information efficiently and effectively, evaluate information critically and competently, and use information accurately and creatively to handle the issues or problems encountered. In addition, information frailty is characterized by fundamental understanding regarding ethical and legal issues in terms of accessing and 
using information. Second, the weakness of the media is shown by understanding how the media is formed, for what purpose, and using what tools, characteristics and conventions. In addition individuals who are media literate can observe how people interpret messages differently, how values and views are covered or set aside, and how the media can influence beliefs and behavior. Likewise, people who are literate in the media will have a basic understanding of ethical and legal issues related to the media itself. Third, with ICT literacy, people will use the right digital technology, communication tools and / or networks to access, manage, integrate, evaluate, and make information work in a knowledge-based economy. He will also be able to use technology as a tool for researching, organizing, evaluating, and communicating information, and of course understanding regarding ethical and legal issues related to this.

If the things that have been delivered can be done by the teacher, of course all the competencies that must be achieved in the learning process will be able to reap maximum results. But sometimes, there are many factors that affect each goal to be achieved so that things can not go well as expected. Likewise, what happened in the learning process conducted by teachers in class IX in 2019/2020 academic year that the average value of student learning achievement reached 50 with a level of mastery learning that only reached $50 \%$. This result is far from the expectation of achieving minimum standard score in Indonesian subjects, namely 65 . The weaknesses obtained from the daily observations are students are embarrassed to ask the teacher and afraid to issue opinions.

The gap between expectations and reality makes researchers as teachers in SMP Negeri 2 Bintan have to work to improve the quality of learning primarily on Indonesian subjects, the alternative action taken by teachers is to improve the learning process using expository models / methods. The use of this model / method is based on the results of consultation with fellow teachers and see the truth of the theory presented in the next chapter. Learning by applying an expository model / method is one of the learning models, especially concerning the skills of teachers in designing, developing, and managing learning systems. Thus, the expository model / method is sought in learning as a solution in overcoming the problem of low learning achievement of class IX even semester students at SMP Negeri 2 Bintan which is formulated as the title "Improving Ninth Grade Students' Comprehension in Learning "Indonesian Language by Implementing Peer-Tutor Strategy in SMP N 2 Bintan".

\subsection{Research Context}

In this research context, the video here was made by the students themselves. First, they (in a group with free topic) speak English with the same distribution of turn talk. It means, each member of group, gets the same chance of turn talk. Everyone was obliged to speak English. Second, someone else recorded their speaking action. After that, by using multimedia (laptop and in-focus), they watch and evaluate the video together. One group, evaluate other group's speaking video recording which is presented via in-focus in front of the class. The aspects to be evaluated were related to the speaking skills development namely: pronunciation, fluency, word choice, structure, self-confidence, teamwork and creativity. 


\subsection{Literary Review}

The success of a teaching program is not caused by one type of resource, but is caused by a combination of various resources that support each other into an integral system. In a broad sense the source of learning does not have to be always the teacher. Learning resources can be other people who are not teachers, but friends from higher classes, classmates, or family at home. Learning resources are not teachers and come from smarter people called tutors. There are two types of tutors, namely peer tutors and sister tutors. Peer tutors are smarter peers, and sister tutors are tutors from higher classes.

Learning strategy using peer tutors is a learning strategy that utilizes other students who have higher abilities to help their friends in mastering the subject matter being taught. Students who have the ability to absorb the subject matter more quickly will help students who absorb the material less quickly.

The language of peers is easier to understand, besides that with peers there is no sense of reluctance, inferiority, shame, and so on so that it is expected that students who lack understanding do not hesitate to express the difficulties they face (Suherman: 2003: 277). Guided group discussion with a peer tutoring model is a discussion group consisting of 5-6 students in each class under the guidance of subject teachers using peer tutors. According to Ischak and Warji in Suherman (2003: 276) argued that "Peer tutors are a group of students who have completed the learning material, giving assistance to students who have difficulty in understanding the learning material learned". Remembering that students are the main elements in teaching that can ultimately change their behavior as expected.

Peer tutors are one model of cooperative learning. According to Arends (1997: 111), learning that uses a cooperative model has the following characteristics: students work in groups cooperatively to complete learning material, groups are formed from students who have high, medium, low ability, if possible, group members come from from race, culture, ethnicity, different sexes, respect is more group oriented than individual (Azizah, 2010: 20).

Utilizing this way of learning can help accelerate the transformation of knowledge delivered to all students and can make students study harder, more active, creative, and fun. The peer tutor learning model will bring to life a competitive atmosphere, so that each group will continue to be motivated to become the best group. Therefore, in addition to the activities of group members, the role of the group leader or tutor has a great influence on the success of the group in learning the teaching material presented. The group leader is democratically elected by all students. For example, if there are 46 students in a class, there are 9 groups with the note that there is a group of 6 students. Before group discussion is formed, students need to submit prospective tutors. A tutor should have the following criteria: 1. Having academic ability above the average student in one class; 2 . Able to establish cooperation with fellow students; 3 . Have high motivation to achieve good academic performance; 4. Having tolerance and tolerance with others; 5 . Have high motivation to make the discussion group the best; 6 . Be humble, brave and responsible; and 7. Like to help others who have difficulty (Azizah, 2010: 19).

According to Hamalik (1998: 163) the stages of preparation using the peer tutor approach are as follows: 1. The teacher makes a teaching program one subject that is designed in the form of sub-subject fragments. Each part of a meeting that includes the title of a fragment of learning objectives, specifically the instructions for carrying out the tasks that must be 
completed; 2. Determine several students who meet the criteria as peer tutors. The number of peer tutors appointed is adjusted to the number of groups formed; 3 . Conduct training for tutors. In implementing this tutorial or guidance, students who become tutors act as teachers. So that the training conducted by the teacher is a kind of teacher or student education. The exercises are held in two ways, namely through small group exercises where in this case only students will become tutors, and through classical exercises, where students throughout the class are trained in how this guidance process takes place; 4. Grouping students into small groups of 4-6 participants. This group is arranged based on variations in the level of student intelligence. Then the appointed peer tutors are distributed to each group that has been determined (Sabarudin, 2009: 13).

\section{Method}

This research is a Classroom Action Research (CAR). The location of this research is at SMP Negeri 2 Bintan. This research took place in three months, namely: January to March the implementation will take place in two cycles. Each cycle in this study consisted of four stages, namely: 1. Planning phase, 2. Implementation phase, 3. Observation stage, and 4. Reflection stage. The subjects of the study were students of class IX E SMP N 2 Bintan after applying the Expository Learning Model with Peer Tutor Strategy.

Data collection techniques in this study used test and observation techniques with their implementation at the end of each cycle through the post test. The test used to measure learning achievement is a performance test that assigns students to find and conclude information in the text. Observation is used to obtain data about the situation of teaching and learning activities in class, and students' difficulties in finding and summarizing information in the text. The observation technique used by researchers is the observation of students. Data analysis was performed using qualitative description techniques.

The indicator of success used in this study is the level of success measured from the average post-test of students, that is, if it has reached the same as or exceeding the KKM 65, classically the average mastery learning has exceeded $85 \%$.

\subsection{Respondents}

The respondents of this study were 36 students of Ninth grade Junior High School in SMP N 2 Bintan. The sample was chosen purposively since it was the class that the researcher has taught in that academic year. From the total respondents, they are 17 male students and the rests are female.

\subsection{Instruments}

The instrument of collecting data in this study was achievement test in the form of multiple choice format. The items were designed in order to fit basic competencies in the curriculum. The instrument in developing the materials and the tests considers the following indicators:

\begin{tabular}{llll}
\hline \multicolumn{1}{c}{ Competence } & Basic Competency & Topic & \multicolumn{1}{c}{ Indicator } \\
\hline $\begin{array}{l}\text { Understanding } \\
\text { knowledge (factual, } \\
\text { conceptual, and }\end{array}$ & $\begin{array}{l}\text { Identify } \\
\text { information in the } \\
\text { form of criticism or }\end{array}$ & Response Text & $\begin{array}{l}\text { Able to explain the } \\
\text { understanding of } \\
\text { response texts. }\end{array}$ \\
\hline
\end{tabular}




\begin{tabular}{|c|c|c|c|}
\hline $\begin{array}{l}\text { procedural) based } \\
\text { on curiosity about } \\
\text { science, } \\
\text { technology, art, } \\
\text { culture related to } \\
\text { phenomena and } \\
\text { events seen in the } \\
\text { eye. }\end{array}$ & $\begin{array}{l}\text { praise from the } \\
\text { response texts } \\
\text { (environment, } \\
\text { social conditions, } \\
\text { or cultural } \\
\text { diversity, etc.) that } \\
\text { are heard or read. }\end{array}$ & $\begin{array}{l}\text { - Understanding } \\
\text { the response } \\
\text { text } \\
\text { - Response text } \\
\text { function } \\
\text { - Characteristics } \\
\text { of response } \\
\text { texts } \\
\text { - Types of } \\
\text { response texts } \\
\text { - Important } \\
\text { information in } \\
\text { the response } \\
\text { text } \\
\text { - Types of } \\
\text { response } \\
\text { sentences }\end{array}$ & $\begin{array}{l}\text { - Be able to explain the } \\
\text { characteristics of the } \\
\text { response text. } \\
\text { - Be able to determine the } \\
\text { types of response texts. } \\
\text { - Able to identify } \\
\text { response texts. } \\
\text { - Able to respond to the } \\
\text { contents of the response } \\
\text { text. } \\
\text { - Being able to determine } \\
\text { information in the } \\
\text { response text, } \\
\text { - Be able to determine the } \\
\text { type of response } \\
\text { sentence. }\end{array}$ \\
\hline
\end{tabular}

\begin{tabular}{|c|c|c|c|}
\hline $\begin{array}{l}\text { Trying, processing, } \\
\text { and presenting in } \\
\text { the realm of } \\
\text { concrete (using, } \\
\text { unraveling, } \\
\text { composing, } \\
\text { modifying, and } \\
\text { making) and } \\
\text { abstract domains } \\
\text { (writing, reading, } \\
\text { calculating, } \\
\text { drawing and } \\
\text { composing) in } \\
\text { accordance with } \\
\text { what is learned in } \\
\text { school and other } \\
\text { sources in the same } \\
\text { perspective / } \\
\text { theory. }\end{array}$ & $\begin{array}{l}\text { Summing up the } \\
\text { contents of the } \\
\text { response text in the } \\
\text { form of criticism or } \\
\text { praise (regarding } \\
\text { the environment, } \\
\text { social conditions, } \\
\text { or cultural } \\
\text { diversity) that is } \\
\text { heard and read. }\end{array}$ & $\begin{array}{l}\text { - The main ideas in } \\
\text { the response text } \\
\text { - Text summary of } \\
\text { responses } \\
\text { - Conclusions of } \\
\text { response texts }\end{array}$ & $\begin{array}{l}\text { - Able to determine the } \\
\text { main ideas in the } \\
\text { response text. } \\
\text { - Able to make a summary } \\
\text { of the contents of the } \\
\text { response text. } \\
\text { - Able to infer the contents } \\
\text { of the response text. }\end{array}$ \\
\hline
\end{tabular}

\subsection{Procedures}

The study was conducted from January to March. All of the stages were planned before as it can be seen in the following list:

1. Preparation of proposals and implementation of initial activities

2. Action planning I

3. Implementation of actions I

4. Observation / data collection I

5. Reflection I 
6. Action planning II

7. Implementation of action II

8. Observation / data collection II

9. Reflection II

10. Report writing

\subsection{Data Analysis}

The method used to analyze the data from the results of this study is descriptive method. For quantitative data analyzed by finding mean, median, mode, making class intervals and presenting in the form of tables and graphs.

\section{Finding and Discussion}

In this study, the findings were found from pre-test as the initial test to reveal students' initial ability, test of first cycle, and test of second cycle. The display of those scores are as follow:

\begin{tabular}{|lcccc|}
\hline No & & Scores & $\begin{array}{c}\text { Improvement } \\
\text { from Cycle-1 to } \\
\text { Cycle-2 }\end{array}$ \\
\hline 1 & Pre-test & Cycle-1 & Cycle-2 & 30 \\
\hline 2 & 40 & 60 & 90 & 25 \\
\hline 3 & 80 & 60 & 85 & 5 \\
\hline 4 & 40 & 50 & 85 & 40 \\
\hline 5 & 40 & 50 & 90 & 30 \\
\hline 6 & 80 & 80 & 90 & 10 \\
\hline 7 & 40 & 65 & 60 & 5 \\
\hline 8 & 40 & 50 & 75 & 25 \\
\hline 9 & 80 & 80 & 80 & 0 \\
\hline 10 & 40 & 65 & 70 & 5 \\
\hline 11 & 40 & 50 & 55 & 5 \\
\hline 12 & 50 & 70 & 85 & 15 \\
\hline 13 & 30 & 50 & 85 & 35 \\
\hline 14 & 50 & 65 & 75 & 10 \\
\hline 15 & 50 & 70 & 90 & 20 \\
\hline
\end{tabular}




\begin{tabular}{|c|c|c|c|c|}
\hline 16 & 80 & 100 & 100 & 0 \\
\hline 17 & 50 & 70 & 80 & 10 \\
\hline 18 & 50 & 70 & 70 & 0 \\
\hline 19 & 80 & 70 & 90 & 20 \\
\hline 20 & 30 & 50 & 80 & 30 \\
\hline 21 & 30 & 50 & 90 & 40 \\
\hline 22 & 80 & 70 & 90 & 20 \\
\hline 23 & 40 & 70 & 90 & 20 \\
\hline 24 & 80 & 70 & 90 & 20 \\
\hline 25 & 80 & 80 & 85 & 5 \\
\hline 26 & 30 & 50 & 50 & 0 \\
\hline 27 & 30 & 50 & 80 & 30 \\
\hline 28 & 30 & 50 & 60 & 10 \\
\hline 29 & 30 & 50 & 60 & 10 \\
\hline 30 & 80 & 80 & 80 & 0 \\
\hline 31 & 50 & 70 & 85 & 15 \\
\hline 32 & 80 & 80 & 90 & 10 \\
\hline 33 & 40 & 70 & 90 & 30 \\
\hline 34 & 30 & 50 & 80 & 30 \\
\hline 35 & 30 & 50 & 85 & 35 \\
\hline 36 & 30 & 50 & 65 & 15 \\
\hline
\end{tabular}

This can be seen from the preliminary data which shows that only 10 students who score 65 and above and 26 students who score below 65, this means that students' learning completeness is only $28 \%$ since 65 is the minimum score as passed-score category. The low learning outcomes of students due to the learning carried out by teachers is still conventional so that students feel less interested in teacher learning.

In the cycle I, the processes are started with the definition of the problem, continuing to the assessment prepared, continuing to formulate a hypothesis, continuing to develop for action I, then implementing the action, evaluation of the action continues to the next application. 
Observations were made after the learning process was carried out in 3 meetings by providing learning achievement tests. In this observation the researcher supervises students closely so that no student cooperates in working on the problems.

Reflection is a comprehensive study of the actions that have been carried out based on the data that has been collected, then an evaluation is carried out to improve the action. Reflection involves the analysis, synthesis, and evaluation of observations of actions taken (Hopkin, 1993 in Suharsimi Arikunto, Suhardjono, Supardi, 2006: 80).

In the cycle II, the phases are redefining existing problems, continuing to prepared assessments, continuing to thinking about the emergence of new hypotheses, improving actions on plan 2, implementing actions, evaluating all implementation and implementation.

Based on the results of research that has been carried out in two cycles shows an improvement in learning outcomes in responding and inferring the text of responses in Indonesian Language learning in Class IX E students through the Expository model with Peer Tutor strategy.

From the scores resulted in pre- and two cycles, the average student learning outcomes increased from 50 in pre-study to 63.75 in the first cycle, this identified an increase of 13.75 in cycle I. In the second cycle the average student learning outcomes to be 80 means there is an improvement. In the first cycle students completeness was $55 \%$ in the category of incomplete, and in cycle II completeness was $86 \%$ in the completeness category. That means the completeness obtained in this second cycle has exceeded $85 \%$ completeness. Based on these results, the researchers decided to stop the next action.

Based on the results of the data it can be said that students enjoy learning Indonesian using the Expository model with Peer Tutor strategy. Students feel easier to understand, more confident, easier to express ideas and more enthusiastic in learning.

\section{Conclusion}

Based on the elaboration of the results of research and discussion that has been described in the previous chapter, it can be concluded that the application of learning with the Expository model with Peer Tutor Strategy can improve student achievement in class IX E SMP Negeri 2 Bintan. It was supported by the results of the study which show in the first cycle the average score was 63.75 and in the second cycle it became 80. From this display, the implementation of Peer Tutor helps students to accomplish learning activities in the classroom.

This study also has limitation in some aspect such as the absent of controlling the external variables. Therefore, for the future study related to Peer Tutor, helping hands from partner or other teachers may be helpful since paying attention on students' activities in the classroom needs more eyes. The current study also reveals there are rooms for teachers to explore more alternative teaching and learning strategy in order to make the classroom interaction alive. 


\section{References}

Ali, Muhammad. (2000). Guru dalam proses Belajar Mengajar. Penerbit: Sinar Baru Algesindo. Bandung.

Arif Furchan. (2004). Pengantar Penelitian dalam Pendidikan. Pustaka Belajar. Yogyakarta.

Dimyati \& Mudjiono. (1994). Belajar dan Pembelajaran. Jakarta: Rineka Cipta.

Grubbs, N and Boes, S.R. (2009). The Effects of the Peer Tutoring Program: An Action Research Study of the Effectiveness of the Peer Tutoring Program at One Suburban Middle School. GSCA, 16(1): 21-31.

Hamalik, Oemar. (2002). Pendidikan Guru berdasarkan Pendekatan Kompetensi. Jakarta Bumi Aksara.

Hamalik , Oemar. (2002). Psikologi Belajar dan Mengajar. Bandung : Sinar Baru.

Hughes, R. (2002). Teaching and researching speaking. UK: Pearson Education Limited.

Koyan, I Wayan. (2008). Konsep Dasar dan Teknik Evaluasi Hasil Belajar. Singaraja: IKIP Singaraja.

Rianto, Milan. (2006). Pendekatan, Strategi dan Metode Pembelajaran. Bahan AjarDiklat Mata Pelajaran Pendidikan Kewarganegaraan SMA Jenjang Dasar. Direktorat Jendral Peningkatan Mutu Pendidik dan Tenaga Kependidikan. Departemen Pendidikan Nasional. Pusat Pengembangan Penataran Guru IPS dan PMP. Malang.

Richards, Jack C. (1994). New Ways in Teaching Speaking USA. Pantagraph Printing.

Sudjana, Nana. (1989) Dasar-dasar Proses Belajar Mengajar. Cetakan ke- 11. Penerbit: Sinar Baru Algesindo. Bandung.

Tabrani Rusyan. (1989). Pendekatan Dalam Proses Belajar Mengajar. Bandung: Remaja Rosdakarya

Thornbury, S. (2005). How to teach speaking. England: Pearson Education limited. 